\title{
Sustainable Tourism Strategy for the City of Kupang's Lasiana Coastal Area
}

\author{
Rulina Yismaya Titu E¹, Santy Paulla Dewi, ST, MT, PhD
}

Received: 28 January 2020

Accepted: 23 May 2020

\begin{abstract}
The integrated and sustainable coastal tourism development activities can contribute to an area both in increasing the income of the government and the local community. The Lasiana coastal area of Kupang City has both natural and cultural potential, location, but it has not been implemented optimally. This study aims to determine the development strategy of the Lasiana coastal area based on the opinion of tourists and local communities in supporting development. This research is quantitative descriptive. The approach in this study is a quantitative approach to describe respondents' responses to attractions based on the questionnaire given. The results showed that the perception of local people and tourists is very influential in determining the area development strategy. The strategies used include the provision of facilities and infrastructure, the provision of a master plan for regional tourism development, traffic management arrangements, human resource development, the development of attractions as well as for cooperation among parties in terms of promotion and maintaining the sustainability of tourism and the environment.
\end{abstract}

Keywords: Sustainable development strategies, coastal areas, tourist perceptions, local communities

\section{INTRODUCTION}

The development of the tourist area is one of the planning projects in Indonesia that is highly incessant by the local government in developing its territory. Indonesia consists of various islands from the west to the east has the uniqueness and characteristics of the tours offered. The Province of East Nusa Tenggara (NTT), is an alternative tourism destination in Eastern Indonesia. In 2007 the local government set tourism as a leading destination (Toda, 2016). Determination of East Nusa Tenggara, as a gateway for Asia-Pacific based tourism, arts and culture precisely in 2013 in the activities of the Komodo sail, NTT has an impact for the province to attract tourism to visit. The potential of this tourist area is utilized by the City of Kupang as a gateway for the development and development of its region. Because the capital city of East Nusa Tenggara is the city of Kupang which has access to airports and ports as a transit route for tourists connecting the local area in East Nusa Tenggara. Kupang City has a geographical location that is dominated by the marine sector. This makes the coastal area of the city of Kupang an attraction for the development of tourist areas. Lasiana's strategic coastal area located in Kelapa Lima District is one of the development of tourist destinations in the province of NTT, namely the existence of Lasiana Beach which is one of the mainstay DTWs in Kupang City due to its natural potential (sea and beach), community lifestyle, and other recreation. This region also has a role and function, namely as one of the nodes, because this area is traversed by one of the national roads that cross Timor-Leste. The master plan for the development of the tourism area of Kupang City is not yet available so that the direction of the development of the

${ }^{1}$ Departemen Perencanaan Wilayah dan Kota Universitas Diponegoro 
coastal area of Lasiana is still as general as other tours that have not been able to make the most of the potential and culture of the existing coastal area. Jandry (2015), provides an explanation of the picture of tourism in the Lasiana coastal area which says that there is a change in the existence of the environment both naturally and that is carried out by managers and communities around the area. Based on these studies it can be said that this region requires control and strategy in development. During this time the coastal area of Lasiana is only a crossing place limited to seeing the natural scenery only by tourists and in a short time. This condition is caused by the attraction possessed by the tourism object which is not yet supported by the presence of adequate tourism facilities and infrastructure. This can be seen in the last few years the increase in the number of local tourists, especially in East Nusa Tenggara, is more in the Flores and Sumba regions, with regard to the City the number of Kupang City visits is only a transit area. Attraction in the coastal area of Lasiana, Kupang City has the potential but has not been able to develop in accordance with its potential. The local government has made a strategy for tourism development but this strategy has not made significant progress. This strategy is captured through the perceptions of tourists and local people. This strategy is expected to be able to optimize and answer the needs of tourists as well as to be able to improve the opinion of local communities while maintaining sustainability in tourism development. Lasiana coastal tourism is expected to create a balanced, harmonious relationship with attention to the quality of tourist experiences, the quality of tourism resources, and the quality of life of the local community so as to create sustainable development.

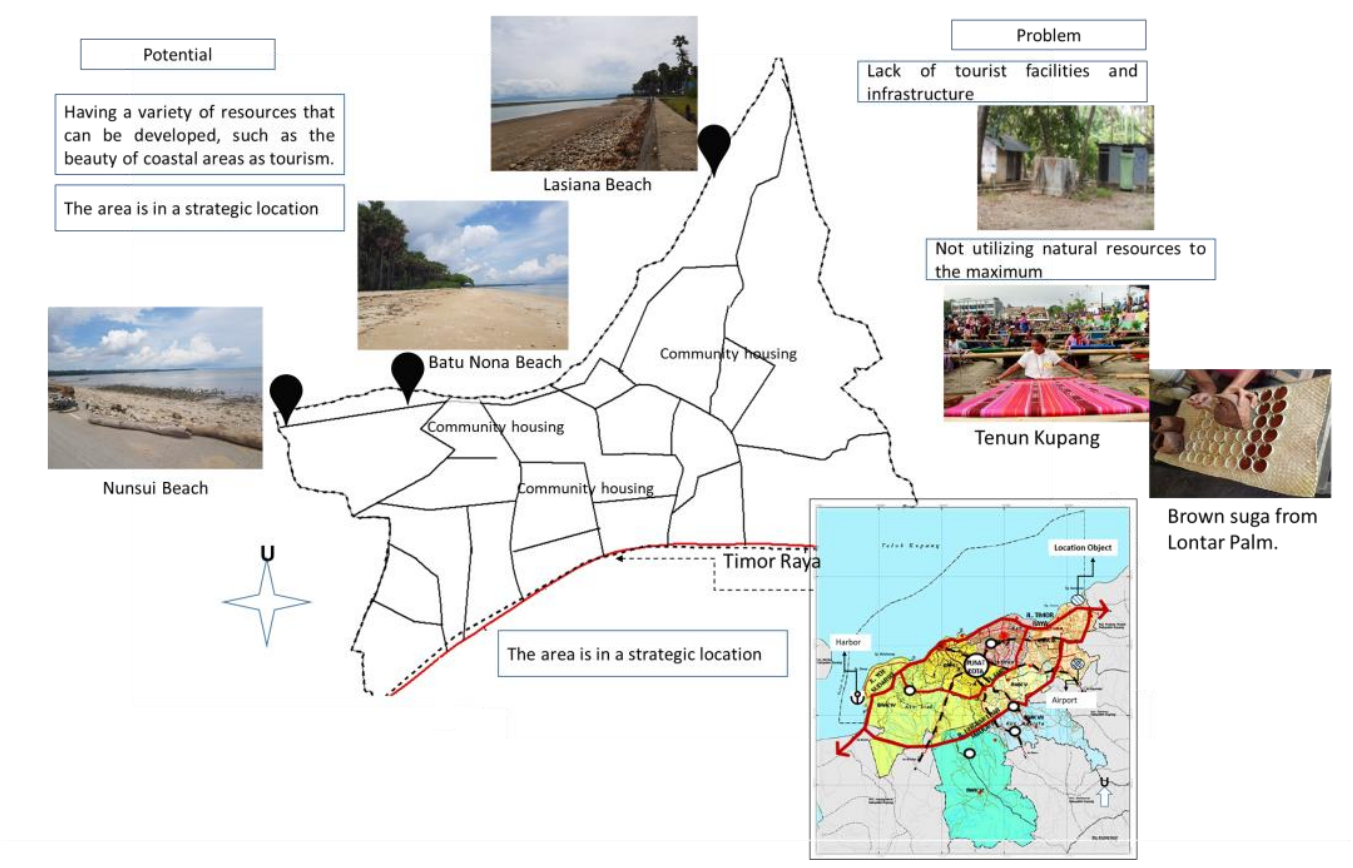

Source: author,2019

Figure 1. Location Coastal Lasiana

\section{METHOD}

The research method consists of data collection methods, methods for sampling and analysis methods. Data were collected by observation, questionnaire, and review 
documents. The research location in the Village area of coastal Lasiana Lasiana, Kupang (figure1). In sampling for the people who live around the area used random sampling method, because it is assumed votes region associated with their activity in coastal areas and with a sample size of 30 people with the assumption that the opinion of each local community is different, and is used purposive sampling method to determine the respondent visitor questionnaires rating based on the number of tourists who come to use the formula solvin, ie a total of 100 respondents, so the number of respondents to the questionnaire was 130 respondents. Processing data using excel with the calculation of the percentage, then the presentation of the data is displayed through charts and travelers penjelasan. Persepsi on performance appraisal and expectations on the attraction of coastal areas Lasiana. Questionnaire consists of three aspects: attractions, facilities and services, and Aksesbiltas \& infrastructure that includes 26 statements that represent every aspect. The processing of data using Excel and SPSS version 22. Steps taken are inputting data and checking whether the data is complete for each answer given. Input data based on the assessment by the Likert scale 1-4, the value of 1 indicates very dissatisfied, 2 declared values are not satisfied, the value of 3 said they were satisfied and very satisfied value of 4 states. . Input data is done in Excel. This analysis compares the mean between expectations with reality according three aspects that exist. Satisfaction is highest when the reality exceeded expectations, namely when the service given maximum four lowest scored scored one and vice versa. So it can be translated internally gap value gap as follows.

Table 1 Classification GAP

\begin{tabular}{cll}
\hline Interval & Classification & level of Satisfaction \\
\hline-3 to -1.5 & very Negative & Very Less Satisfied appeal hope \\
-1.5 sd 0 & Negative & Less Satisfied appeal hope \\
From 0 to 1.5 & Positive & More Satisfied appeal hope \\
1.5 to 3 & very Positive & Very More Satisfied appeal hope \\
Source: Djunaidi, et al, 2006 & &
\end{tabular}

Further depicted in a Cartesian diagram which describes the level of statements into four parts which can be determined by this diagram are several factors that affect tourist satisfaction which can then be prioritized for further increased.Combining measurements of the level of interest and satisfaction factors in graphs that facilitate explanation of data and get a free proposal. From the results of the questionnaires processed data analysis techniques related to strategy development using SWOT mostly captured by the results that have been processed.

\section{RESULT}

\section{Perception of the Tourist Community}

Based on the results of the questionnaire, it can be seen the characteristics of tourists, tourist characteristics are key in determining the market or targets, and some components are considered to determine the concepts in regional development.

Table 2. Characteristics of Tourists

\begin{tabular}{lllr}
\hline No & Respoden identity & Sub-category & Percentage (\%) \\
\hline 1 & Age & $<20$ & 33,0 \\
& & $21-30$ & 40,0 \\
& & $31-40$ & 24,0 \\
& & 41 & 3,0 \\
2 & \multirow{2}{*}{ Education level } & Elementary School & 5,0 \\
& & Junior High School & 21,0 \\
& & Senior High School & 52,0 \\
& & College & 13,0 \\
& & etc & 9,0 \\
\hline
\end{tabular}




\begin{tabular}{|c|c|c|c|}
\hline No & Respoden identity & Sub-category & Percentage (\%) \\
\hline \multirow[t]{5}{*}{3} & \multirow[t]{5}{*}{ Jobs } & Student & 36,0 \\
\hline & & Private employee & 27,0 \\
\hline & & Civil servant & 14,0 \\
\hline & & Fishermen & 22,0 \\
\hline & & etc & 1,0 \\
\hline \multirow[t]{3}{*}{4} & \multirow[t]{3}{*}{ Countries of residence } & Kupang & 69,3 \\
\hline & & $\begin{array}{l}\text { Countryside of Kupang but still } \\
\text { the province of NTT }\end{array}$ & 29,7 \\
\hline & & Country & 1,0 \\
\hline \multirow[t]{3}{*}{5} & \multirow[t]{3}{*}{ Transportation } & Private & 81,2 \\
\hline & & Public & 12,9 \\
\hline & & etc & 5,0 \\
\hline \multirow[t]{6}{*}{6} & \multirow[t]{6}{*}{ The purpose of the visit } & Recreation & 64,4 \\
\hline & & Visit & 15,8 \\
\hline & & Research & 0,0 \\
\hline & & Ritual /culture & 12,9 \\
\hline & & Sport & 4,0 \\
\hline & & etc & 1,0 \\
\hline \multirow[t]{4}{*}{7} & \multirow{4}{*}{$\begin{array}{l}\text { Information/Source } \\
\text { place }\end{array}$} & Friends/Family & 61,4 \\
\hline & & Travel agenct & 1,0 \\
\hline & & Internet or media social & 35,6 \\
\hline & & $\begin{array}{l}\text { Print media: newspapers, } \\
\text { magazines. }\end{array}$ & 1,0 \\
\hline \multirow[t]{3}{*}{8} & \multirow[t]{3}{*}{ Visiting hours } & $<30$ minutes & 7,9 \\
\hline & & 1 hours & 48,5 \\
\hline & & 2-3 hours & 43,6 \\
\hline \multirow[t]{4}{*}{9} & \multirow[t]{4}{*}{ Costs } & $<\operatorname{Rp} 50.000$ & 52,5 \\
\hline & & Rp $50.000-150.000$ & 44,5 \\
\hline & & RP $200.000-500.000$ & 2,0 \\
\hline & & $>$ Rp 500.000 & 1,0 \\
\hline
\end{tabular}

Source: by the author,2019.

The average productive age, which is the age that is ready to work or students is the most respondents. The livelihood characteristics of half of the response of visitors to tourist objects are students or students. This fact relates to the analysis of the majority of the age groups of students who come with friends or other students just visiting. Tourism development needs to look at the characteristics of transport modes with regard to the value of ease in reaching tourist attractions, as a large use of private vehicles, the location also encourages visiting tourists to existing objects from the city of Kupang alone. Based on the observation of the length of stay, the average traveler is assumed to be one day, no more than 24 hours. The longer the visit time is expected, the greater the expenditure, but this is very correlated with the results of the costs not exceeding Rp.50,000. Economic benefits for businesses that are around tourism objects.

\section{Analysis of tourist perception}

This analysis regarding the opinion of visitors or tourists related to several aspects of the development of attractions. The purpose of this analysis is to find out which aspects of special attention are needed in further development. The level of performance and expectations consists of several aspects, namely (1) tourist attractions, (2) facilities and services and (3) accessibility and infrastructure. Based on the results of the questionnaire and this study will find out some components of the three aspects above that indicate the existence of positive and negative perceptions. Analysis of each aspect based on the order from the largest gap to the smallest gap can be described as follows:

\section{Aspects of tourism Attractions}

The tourist attraction shows the natural and environmental conditions of a location that has superior natural resources, as well as an interesting culture. In table 3, the largest gap in the aspect of tourist attraction is the availability of cultural attractions (statement 4) 
of -1.5 and the smallest concerning authenticity and protection of coastal areas (statements $1 \& 5$ ) of -0.15 . The assessment of aspects of tourist attraction has a mean performance score of 2.9 and a mean expectation score of 3.5 so that the gap that occurs is -0.5 . The mean resulting from the gap between expectations and performance in the aspect of tourist attraction produces a value of service quality of $83.8 \%$. Based on Tables 1 , the gap value of -0.5 indicates a negative classification gap. This shows that tourists are not satisfied with the performance given in the aspect of tourist attraction.

Table 3. Characteristics of tourists

\begin{tabular}{|c|c|c|c|c|c|c|}
\hline \\
\hline No & Aspect & Sub Variable Aspect & $\mathrm{X}$ & $\mathrm{Y}$ & GAP & Tki(\%) \\
\hline 1 & \multirow[t]{8}{*}{$\begin{array}{l}\text { Tourism } \\
\text { Actraction }\end{array}$} & \multirow{3}{*}{$\begin{array}{l}\text { Natural environment tourist \& } \\
\text { beautiful } \\
\text { In the beach with white sand } \\
\text { spread } \\
\text { Air condition a natural }\end{array}$} & 3,51 & 3,66 & $-0,15$ & 95,9 \\
\hline 2 & & & 2,93 & 3,9 & $-0,97$ & 75,1 \\
\hline 3 & & & 3,78 & 3,93 & $-0,15$ & 96,2 \\
\hline 4 & & $\begin{array}{l}\text { The existence of culture } \\
\text { attraction }\end{array}$ & 1,94 & 3,44 & $-1,5$ & 56,4 \\
\hline 5 & & \multirow{2}{*}{$\begin{array}{l}\text { The preservation of on the } \\
\text { existence of Palmyra Palms } \\
\text { comfort zone }\end{array}$} & 3 & 3,15 & $-0,15$ & 95,2 \\
\hline 6 & & & 3 & 3,3 & $-0,3$ & 90,9 \\
\hline \multirow[t]{2}{*}{7} & & $\begin{array}{l}\text { Need new an interesting } \\
\text { attraction }\end{array}$ & 2,33 & 3,04 & $-0,71$ & 76,6 \\
\hline & & Mean & 2,92 & 3,5 & $-0,56$ & 83,8 \\
\hline 8 & \multirow{14}{*}{$\begin{array}{l}\text { facilities and } \\
\text { services }\end{array}$} & Parking Available & 3,28 & 3,32 & $-0,04$ & 98,8 \\
\hline 9 & & Available Information center & 2,56 & 2,64 & $-0,08$ & 97 \\
\hline 10 & & Available the trash & 2,67 & 3,31 & $-0,64$ & 80,7 \\
\hline 11 & & Available Hut & 3,02 & 3,42 & $-0,4$ & 88,3 \\
\hline 12 & & $\begin{array}{l}\text { Available Toilet and fresh } \\
\text { water }\end{array}$ & 2,02 & 3,28 & $-1,26$ & 61,6 \\
\hline 13 & & Available Mushola & 2,43 & 3,16 & $-0,73$ & 76,9 \\
\hline 14 & & Available Souvenir Shop & 2,06 & 2,72 & $-0,66$ & 75,7 \\
\hline 15 & & Lodging is available & 2,98 & 3 & $-0,02$ & 99,3 \\
\hline 16 & & Available food restaurants & 2.95 & 2,98 & $-0,03$ & 99,1 \\
\hline 17 & & Hospitality employees & 3,1 & 3,2 & $-0,1$ & 96,9 \\
\hline 18 & & Security Location & 3,04 & 3,16 & $-0,12$ & 96,2 \\
\hline 19 & & The quality of food & 2,98 & 3,03 & $-0,05$ & 98,3 \\
\hline \multirow[t]{2}{*}{20} & & officers tourism objects & 2,54 & 3,05 & $-0,51$ & 83,3 \\
\hline & & Mean & 2,72 & 3,1 & $-0,36$ & 88,2 \\
\hline 21 & \multirow{7}{*}{$\begin{array}{l}\text { Accessibility } \\
\text { and } \\
\text { Infrastructure }\end{array}$} & Transportation accessible & 3,05 & 3,11 & $-0,06$ & 98,1 \\
\hline 22 & & Acess road & 2,76 & 3,01 & $-0,25$ & 91,7 \\
\hline 23 & & Signage & 2,56 & 2,67 & $-0,11$ & 95,9 \\
\hline 24 & & $\begin{array}{l}\text { Access communication and } \\
\text { electricity }\end{array}$ & 3,05 & 3,12 & $-0,07$ & 97,8 \\
\hline 25 & & Rubbish management & 2,62 & 3,13 & $-0,51$ & 83,7 \\
\hline \multirow[t]{2}{*}{26} & & Waste management & 2,76 & 3,16 & $-0,4$ & 87,3 \\
\hline & & Mean & 2,8 & 3,03 & $-0,23$ & 92,4 \\
\hline
\end{tabular}

Source: by the author,2019. 
2. Facility and Service Aspects

This aspect of facilities and services shows the response of tourists about the condition and quantity of tourist facilities and services which are their own assessment of the perceived experience. The largest value gap for facility and service aspects (table 3 ) is the availability of toilet facilities by -1.26 and the smallest value is -0.05 parking facilities. The gap between the mean score of performance and expectations in the aspects of facilities $\&$ services of -0.36 shows that tourists are less satisfied with the performance provided in the aspects of facilities and services

3. Accessibility and Infrastructure Aspects

Accessibility and infrastructure are important elements in tourism development. Accessibility plays a role in making it easy for tourists to achieve attraction. Infrastructure is an important element in supporting the sustainability of tourism facilities. In table 3 the assessment on accessibility and infrastructure aspects, especially on the mean score of performance and expectations shows a gap of -0.23 which means tourists are less satisfied with the performance given in the aspects of accessibility and infrastructure.

Based on the table above, the existing data needs to be analyzed again in determining the priority scale with a mapping of performance values $(\mathrm{x})$ and expectations (y), a matrix consisting of four quadrants will be formed which describes the priority scale in taking policies in improving performance or maintaining performance in tourist attraction development. The components in the existing aspects are in different quadrants so that the factors that need to be prioritized are the following results:

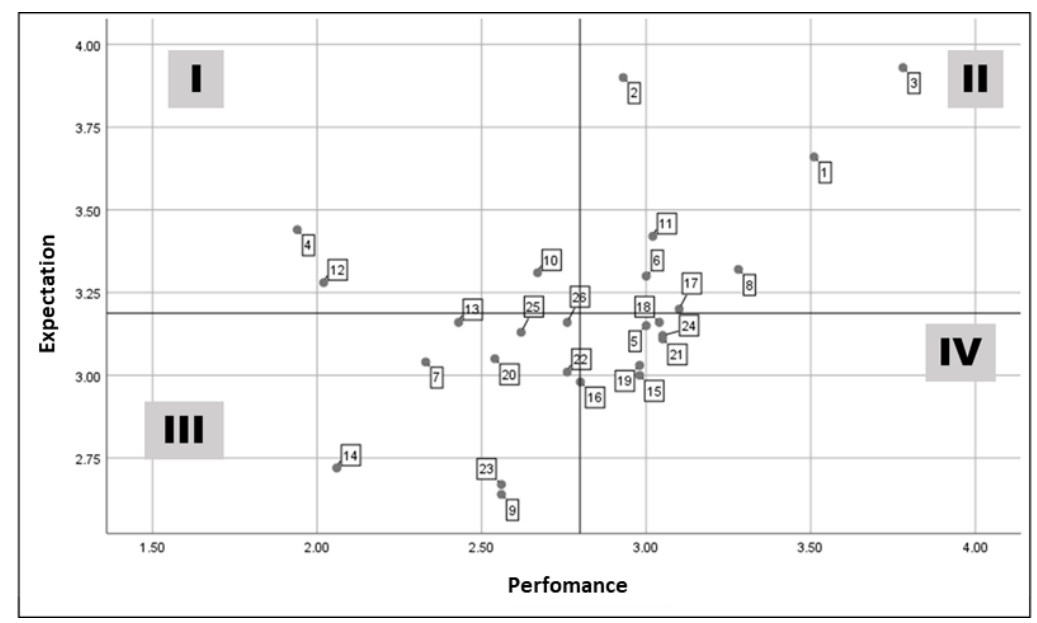

Source: by the author,2019

Figure 2 Cartesian Diagram Results Distribution Attribute

Quadrant I describe the components or attributes that are considered important by visitors, but the implementation is deemed not in accordance with his wishes. Supply of toilet facilities, prayer rooms and trash bins is very necessary. In addition to facilities for easy transportation, it is also important that most tourist attractions in the Lasiana coastal area can only be reached by private vehicles. Attractions and natural scenery are a unity in the attraction of tourist attractions need to be developed, Lasiana has many potential attractions such as weaving cloth, making sugar (gula lempeng) and more.

Quadrant II shows the existence of the existence of service attributes that are considered important and their performance has been considered satisfying by visitors. The attractive aspect for this quadrant is the preservation of the area, the beautiful environment and natural air. As well as several components of facilities that must be maintained 
Quadrant III explains the attributes that are in this quadrant do not have expectations that are too high so that the assessment of importance is not too high and the performance value is normal. The component of attraction in this quadrant is related to attractions in this case the attraction in question is the addition of attractions in the form of water play activities such as banana boating, snorkeling, fishing and others related to interactions around the tourist area, even though it is categorized as low priority but attractions this is part of the opportunity to open a livelihood of the surrounding community.

Quadrant IV explains the attributes that are felt to have exceeded what is desired by visitors. This relates to facilities and servants as well as existing infrastructure. Related facilities for lodging,restaurants and stalls have been felt satisfied for the surrounding community.

Based on Table 4, it can be seen addressing the involvement of the private sector in managing tourism in the coastal area of Lasiana, as many as 50\% of the people agreed and 33\% strongly agreed. The reason is because the community does not have enough capital in tourism development, so they need help from the private sector. Even though most of the community agreed to the involvement of the private sector, the existence of the local community remained as a dominance in all aspects of activities. It also appears that $17 \%$ of people who said they did not agree. The reason is that they are worried because with the involvement of the private sector the more profits will go to the private sector. As many as $17 \%$ of local people assume that they have never been involved in the community in the development of the area because they prefer to give up all activities or development plans are only government matters. Broadly speaking, this Lasiana coastal area is indifferent which causes the involvement of surrounding communities to be very less. Broadly speaking, a summary of the frequency distribution of people's perceptions of tourism development in the coastal area of Lasiana, it can be concluded that the community expressed no objection if the area was developed by tourism but it is necessary to consider again the level of local human resources.

Table 4 Summary of Local Community Responses to Tourism Development in the Lasiana Coastal Region

\begin{tabular}{lllll}
\hline Local Respodent Perception & 1 & 2 & 3 & 4 \\
\hline tourism development & & 0,07 & 0,10 & 0,83 \\
Preservation of attractions & & & 0,13 & 0,87 \\
Community involvement & 0,03 & 0,17 & 0,47 & 0,33 \\
The house as a homestay & & 0,63 & 0,20 & 0,17 \\
Positive influence of tourism & 0,07 & 0,6 & 0,27 & 0,07 \\
Education and training & & 0,17 & 0,50 & 0,33 \\
Private sector involvement & & 0,17 & 0,50 & 0,33 \\
\hline
\end{tabular}

Source: by the author, 2019

In the table 5, developed strategies that can be done for the development of the coastal tourism area of Lasiana. These strategies are contained in the SWOT Analysis Matrix. The SWOT matrix is a matrix that interacts with internal and external strategic factors. SWOT analysis matrix based on the results of the questionnaire and the condition of the existing coastal area of Lasiana

Table 5 Strategies to Guide to Coastal Tourism Area Development Lasiana

\begin{tabular}{lll}
\hline $\begin{array}{l}\text { Identification of } \\
\text { Factors }\end{array}$ & Strength $(\mathrm{S})$ & Weakness (W) \\
\hline & $\begin{array}{l}\text { Having an attractive potential tourist } \\
\text { attraction with sand and attractions } \\
\text { conditions unspoiled }\end{array}$ & $\begin{array}{l}\text { Tourist support infrastructure which } \\
\text { still needs to be improved such as } \\
\text { (provision of toilets, clean water and } \\
\text { the provision of bins) }\end{array}$ \\
& $\begin{array}{l}\text { Lack of tourism attractions that draw } \\
\text { visitors }\end{array}$ \\
& \\
\hline
\end{tabular}




\begin{tabular}{|c|c|c|}
\hline $\begin{array}{l}\text { Identification of } \\
\text { Factors }\end{array}$ & Strength $(\mathrm{S})$ & Weakness (W) \\
\hline & $\begin{array}{l}\text { Roads are around the country and several } \\
\text { nearby districts }\end{array}$ & Lack of community participation \\
\hline & $\begin{array}{l}\text { Natural resources like palm trees that can } \\
\text { be developed }\end{array}$ & \\
\hline & $\begin{array}{l}\text { The location was not far from the } \\
\text { international airport }\end{array}$ & \\
\hline Oportunities $(\mathrm{O})$ & SO & WO \\
\hline $\begin{array}{l}\text { Is the gateway to a } \\
\text { country road, the road } \\
\text { corridor Timor will be } \\
\text { more frequently } \\
\text { traveled highway traffic }\end{array}$ & $\begin{array}{l}\text { Networking with other tourist objects, } \\
\text { especially Kupang in attracting visitors }\end{array}$ & $\begin{array}{l}\text { Developing the interest of tourists by } \\
\text { developing attractions such as the } \\
\text { procurement of khsususnya Lasiana } \\
\text { festival held Flobamora festival is } \\
\text { festival crafts using natural resources } \\
\text { owned (race craft creations made } \\
\text { from natural resources without } \\
\text { damaging the existing natural) }\end{array}$ \\
\hline \multirow{2}{*}{$\begin{array}{l}\text { Located near the } \\
\text { International Airport, it } \\
\text { is becoming a major } \\
\text { factor pulling visitors }\end{array}$} & $\begin{array}{l}\text { Creating traffic management rules coastal } \\
\text { areas Lasiana }\end{array}$ & $\begin{array}{l}\text { Provide and complete the } \\
\text { infrastructure and tourist facilities }\end{array}$ \\
\hline & $\begin{array}{l}\text { Increase cooperation with the government } \\
\text { and other parties in the promotion of coastal } \\
\text { tourist attractions Lasiana }\end{array}$ & $\begin{array}{l}\text { The socialization and collaboration } \\
\text { with local communities in the } \\
\text { development of local businesses. }\end{array}$ \\
\hline Threaths $(\mathrm{T})$ & ST & WT \\
\hline $\begin{array}{l}\text { Part of the coastal } \\
\text { community awareness } \\
\text { is still low }\end{array}$ & $\begin{array}{l}\text { Increase public understanding of the } \\
\text { benefits of socio-cultural resistance }\end{array}$ & $\begin{array}{l}\text { Increasing public awareness of the } \\
\text { importance of the environmental and } \\
\text { sustainable tourism. With the } \\
\text { voluntary work done every once a } \\
\text { month around the area. }\end{array}$ \\
\hline $\begin{array}{l}\text { The location of coastal } \\
\text { areas as well as major } \\
\mathrm{J} 1 \text { corridor is in the } \\
\text { center of the acquisition } \\
\text { target region mejadikan }\end{array}$ & $\begin{array}{l}\text { Formation and preparation of management } \\
\text { institution under the supervision of the } \\
\text { government and the mutually beneficial } \\
\text { cooperation. }\end{array}$ & Preparation of regional infrastructure \\
\hline $\begin{array}{l}\text { Intrusion of foreign } \\
\text { culture to the local } \\
\text { community }\end{array}$ & $\begin{array}{l}\text { Maintain and increase the diversity of } \\
\text { tourist attractions }\end{array}$ & $\begin{array}{l}\text { Providing a Regional Tourism } \\
\text { Development Master Plan and } \\
\text { regulatory support. }\end{array}$ \\
\hline
\end{tabular}

\section{CONCLUSION}

Lasiana coastal area is an area that has the potential for the development of sustainable tourism with cultural richness and natural beauty. But the development is not optimal. Based on research conducted by the character of tourists is the main reason for tourists in visiting destinations that affect tourist behavior as an assessment of tourist satisfaction (Snepenger, 2006). For the Lasiana region, it still cannot attract and interest of visitors, this can be seen from the dissatisfaction with the facilities and infrastructure provided, besides the lack of tourist attractions, so that the Lasiana area is less desirable. Tourist behavior and knowledge will reflect the motivation of tourists who have an important role in tourism marketing in creating tourist requests and visiting decisions (March \& Woodside, 2006). Based on the theory and condition of the existing coastal area of Lasiana still in the stage requires increasing its attractiveness. 
According to Nurhayati (2018) states that the correct knowledge and perception of the community regarding the development of coastal areas in order to build a positive attitude for sustainability towards tourist attraction. Aspects that need to be considered are the availability and quality of attractiveness, accessibility, infrastructure, services and existing facilities (Stange, 2010). So in a sustainable coastal area development strategy based on swot analysis as follows the provision and improvement of facilities and infrastructure in accordance with attractions, increased attractions, provision of regional tourism development master plans, support of traffic management regulations and human resource development and establishing cooperation or partnerships with the private sector and others both in terms of promotion and maintaining the sustainability of the environment.

\section{REFERENCES}

Djunaidi,etc. 2006. Analisis Kepuasan Pelanggan dengan Pendekatan Fuzzy Service Quality dalam Upaya Peningkatan Kualitas Pelayanan, Jurnal Ilmiah Teknik Industri.4(3):139 - 146.

Jandry Pieter, Frederik Benu, \& Michael Riwu Kaho.2015.Valuasi Ekonomi Ekowisata Terhadap Pengembangan Objek Wisata Kawasan Pesisir Pantai (Studi Kasus Jasa Lingkungan Non-Market Sumber Daya Alam Objek Wisata Pesisir Pantai Lasiana Kecamatan Kelapa Lima Kota KupangProvinsi NTT). Jurnal Ilmu Lingkungan Vol.13.

Nurhayati, Amar Maruf \& Nur Arafah.2018. Persepsi dan Sikap Masyarakat Terhadap Pengembangan Ekowisata Mangrove. Ecogreen Vol 4(1):43-51.

R. March and A.G. Woodside. 2005. Tourism behaviour: Travellers decisions and actions. CABI Publishing, Wallingford .ISBN 0-85199-021-5

Snepenger, D. , King, J., Marshall E and Uysal, M. 2006. Modeling Iso-Ahola's Motivation Theory in the Tourism Context. Journal of Travel Research. 45:140

Stange, et al. 2011. Tourism Destination Management Achieving Sustainable and Competitive Results. Washington, DC: George Washington University.

Toda, H. 2016. Arah Pembangunan Nusa Tenggara Timur Sebagai Provinsi Pariwisata Berkelas Dunia. Prosiding Seminar Nasional Kebijakan dan Perencanaan Kota Berwawasan Kesehatan, 26-34. 